\section{REVIEW ARTICLES}

29 Hayes, R. J., Petty, I. T. D., Coutts, R. H. A. \& Buck, K. W. (1988). Gene amplification and expression in plants by a replicating geminivirus vector. Nature 334 , 179-182.

30 Brisson, N., Paszkowski, J., Penswick, J. R., Gronenborn, B., POtrykus, I. \& HOHN, T. (1984), Expression of a bacterial gene in plants by using a viral vector. Nature 310, 511-514.

31 Haynes, J. R., Cunningham, J., Von Seerried, A. Lennick, M., Garvin, R.T. \& Shen, S.-H. (1986) Development of a genetically-engineered, candidate polio vaccine employing the self-assembling properties of the tobacco mosaic virus coat protein. Bio/Technology 4 , 637-641.

32 Harrison, B. D., Mayo, M. A., \& Baulcombe, D.

C. (1987). Virus resistance in transgenic plants that express cucumber mosaic virus satellite RNA. Nature 328, 799-802.

33 MCKinney, H. H. (1929). Mosaic diseases in the Canary Islands, West Africa and Gibralter. J. Agricult. Res. 39, 557-578.

34 Powell Abel, P., Nelson, R. S., De, B., Hoffmann, N., Rogers, S. G., Fraley, R. T. \& Beachy, R. N. (1986). Delay of disease development in transgenic plants that express the tobacco mosaic virus coat protein gene. Science 232, 738-743.

35 Nelson, R. S., Powell Aber, P. \& Beachy, R. N. (1987). Lesions and virus accumulation in inoculated transgenic tobacco plants expressing the coat protein gene of tobacco mosaic virus. Virology 158, 126-132.
36 Register, J. C. \& BeAChY, R. N. (1988). Resistance to TMV in transgenic plants results from interference with an early event in infection. Virology 166, 524-532. 37 Tumer, N. E., O'Connell, K. M., Nelson, R. S. Sanders, P. R., Bfachy, R. N., Fraley, R. T. \& ShaH, D. M. (1987). Expression of alfalfa mosaic virus coat protein gene confers cross-protection in transgenic tobacco and tomato plants. EMBO J. 6, 1181-1189.

38 Loesch-Fries, L. S., Merlo, D., Zinnen, T., Burhop, L., Hill, K., Krahn, K., Jarvis, N., Nelson, S. \& Halk, E. (1987). Expression of alfalfa mosaic virus RNA4 in transgenic plants confers virus resistance. EMBO J.6, 1845-1851.

39 Van Dun, C. M. P., Bol, J. F. \& Van Vloten DotiNG, L. (1987). Expression of alfalfa mosaic virus and tobacco rattle virus coat protein genes in transgenic tobacco plants. Virology 159, 299-305

40 Van Dun, C. M. P., Overduin, B., Van VlotenDoting, L. \& BoL, J.F. (1988). Transgenic tobacco expressing tobacco streak virus or mutated alfalfa mosaic virus coat protein does not cross-protect against alfalfa mosaic virus infection. Virology 164, 383-389.

41 Cuozzo, M., O'Connell, K. M., Kaniewski, W. FANG, R.-X., ChUa, N.-H. \& Tumer, N. E. (1988). Viral protection in transgenic tobacco plants expressing the cucumber mosaic virus coat protein or its antisense RNA. Bio/Technology 6, 549-557.

42 Hemenway, C., Fang, R.-X., Kaniewski, W. K. Chua, N.-H. \& Tumer, N. E. (1988). Analysis of the mechanism of protection in transgenic plants expressing the potato virus $X$ coat protein or its antisense RNA EMBO J. 7, 1273-1280.

43 Nelson, R. S., McCormick, S. M., Delannay, X., Dube, P., Layton, J., Andirson, E. J., Kaniewska, M Proksch, R. K., Horsch, R. B., Rogers, S. G., Fraley, R. T. \& BEACHY, R. N. (1988). Virus tolerance, plant growth, and field performance of transgenic tomato plants expressing coat protein from tobacco mosaic virus. Bio/Technology 6, 403-409.

44 Crum, C., Johnson, J. D., Nelson, A. \& Roth, D. (1988). Complementary oligodeoxynucleotide mediated inhibition of tobacco mosaic virus RNA translation in vitro. Nucl. Acids Res. 16, 4569-4581.

45 Morch, M. D., Joshi, R. L., Denial, T. M. \& HAENNI, A. L. (1987) A new 'sense' RNA approach to block viral RNA replication in vitro. Nucl. Acids Res. 15, 4123-4130.

T. MICHAEL A. WILSON is at the Department of Virus Research, John Innes Institute and AFRC Institute of Plant

Science Research, Colney Lane, Norwich NR4 $7 U H, U . K$.

\title{
The Carbonic Anhydrases: Widening Perspectives on Their Evolution, Expression and Function
}

\author{
Richard E. Tashian
}

\section{Summary}

Now, some 55 years after its discovery in bovine red cells, carbonic anhydrase (CA), in all its varied forms, continues to challenge and intrigue physiologists, biochemists and molecular geneticists. This is so because of an increasing awareness of the many apparently diverse functions of the different $C A$ isozymes encoded by this large multigene family, the continuing discovery of new $C A$, or $C A$ related, genes, and the extensive variation in their hormonal control, cellular expression and subcellular localization.

\section{Introduction}

The carbonic anhydrases (CA) are zinc metalloenzymes that catalyze the simple interconversion of $\mathrm{CO}_{2}$ and $\mathrm{HCO}_{3}{ }^{-}$ $\left(\mathrm{CO}_{2}+\mathrm{O}_{2} \rightleftharpoons \mathrm{HCO}_{3}^{-}+\mathrm{H}^{+}\right)$. They are found in almost all organisms, and are notable for the extremely high turnover numbers (some exceeding $1 \times 10^{6} \mathrm{sec}^{-1}$ ) of the high-activity forms, ranking them along the most efficient enzymes known. They are also distinctive because of the extensive diversity in both the cellular distribution and in the putative or established biological functions of the seven CA isozymes now known to occur in higher vertebrates. Some of the CA genes are expressed in certain cells of nearly all tissues, whereas others appear to be more limited in their distribution. In view of such diversity in expression and function, the CA isozyme system is an excellent model for the study of molecular processes and patterns underlying the evolution and expression of genes derived from a common ancestor. (for recent accounts, see papers in refs. 1 and 2.)

\section{Evolutionary Patterns}

Since the reaction catalyzed by carbonic anhydrase may well have been of widespread adaptive value to the earliest organisms, it is possible that it was among the first enzymes to appear. Since what seem to be evolutionarily related (homologous) forms of carbonic anhydrase are found in certain bacteria and algae, ${ }^{3}$ the original gene probably arose before the divergence of prokaryotes and eukaryotes more than one and a half billion years ago. And during their long evolutionary history the CA genes have undergone many rounds of duplications resulting in new genes, the products of which have been implicated in such diverse processes as calcification, photosynthesis, respiration, acid-base homeostasis, bone resorption, formation of aqueous humor and gastric juice, and the synthesis of urea, glucose and lipids. ${ }^{1,2}$

\section{The Genes}

In terrestrial vertebrates (i.e. amniotes) the carbonic anhydrase system comprises at least 7 genes (Table I). Four of these (coding for CA I, CA II, CA III and CA VII) have now be fully or partially characterized, ${ }^{4-8}$ and with the exception of human CA I, which has a large intron in the $5^{\prime}$ untranslated region, ${ }^{8}$ they all appear to have seven exons, with the six introns at the same positions, and range in size from $9.8 \mathrm{~kb}$ (human CA VII) to $17 \mathrm{~kb}$ (chicken and 
REVIEW ARTICLES

TABLE I. Summary of selected features of the mammalian CA isozymes and viral CA-like proteins*

\begin{tabular}{|c|c|c|c|c|c|}
\hline & $\begin{array}{l}\text { Amino acid } \\
\text { residues }\end{array}$ & $\begin{array}{l}\text { Activity } \\
\left(\mathrm{mol} \sec ^{-1}\right)\end{array}$ & $\begin{array}{l}\text { Chromosome } \\
\text { position }\end{array}$ & Distribution & $\begin{array}{l}\text { Some established and } \\
\text { purported functions }\end{array}$ \\
\hline \multicolumn{6}{|l|}{ CA Isozymes } \\
\hline \multicolumn{6}{|l|}{ Cytosolic } \\
\hline CA II & 259 & $\operatorname{High}\left(\sim 1 \times 10^{6}\right)$ & $\begin{array}{l}\text { Human } 8 \mathrm{q} 22 \\
\text { Mouse } 3\end{array}$ & $\begin{array}{l}\text { Widely distributed in secretory } \\
\text { and absorbing epithelia. Certain } \\
\text { cells of virtually all tissues [e.g. } \\
\text { bone (osteoclasts), braint } \\
\text { (oligodendrocytes), eye (ciliary } \\
\text { body, lens, Müller cells of } \\
\text { retina). liver (perivenous cells), } \\
\text { kidney (tubulcs), salivary glands } \\
\text { (acinar cells), pancreas (ductal } \\
\text { cells), stomach (parietal cells) } \\
\text { and uterus]. Red cells and } \\
\text { platelets. Undetected in } \\
\text { granulocytes, monocytes, } \\
\text { fibroblasts, osteoblasts, and } \\
\text { CNS neurons }\end{array}$ & $\begin{array}{l}\text { Promotion of gas, fluid and ion } \\
\text { transfer. Maintenance of acid- } \\
\text { base homeostasis. } \mathrm{H}^{+} \text {secretion } \\
\text { (gastric juice production, renal } \\
\text { acidification, bone resorption). } \\
\mathrm{HCO}_{3}{ }^{-} \text {secretion (production of } \\
\text { pancreatic juice, CS fluid, } \\
\text { acqueous humor, saliva). } \\
\mathrm{HCO}_{3}^{-} \text {reabsorption, (proximal } \\
\text { renal tubules). } \mathrm{CO}_{2} \text { excretion } \\
\text { and exchange. } \mathrm{Ca}^{+} \text {transport } \\
\text { (placenta). Fatty acid and amino } \\
\text { acid synthesis. } \mathrm{Cl}^{-} \text {exchange } \\
\text { (colon)? }\end{array}$ \\
\hline CA I & 260 & Low $\left(\sim 1 \times 10^{5}\right)$ & $\begin{array}{l}\text { Human } 8 \mathrm{q} 22 \\
\text { Mouse } 3\end{array}$ & $\begin{array}{l}\text { Primarily in red cells, } \\
\text { gastrointestinal epithelia and } \\
\text { vascular endothelium. Also in } \\
\text { such tissues as: eye (corneal } \\
\text { endothelium, lens and ciliary } \\
\text { body epithelium), sweat glands, } \\
\text { salivary glands, adipose cells } \\
\text { and myoepithelial cells }\end{array}$ & $\begin{array}{l}\text { Probably similar to CA II } \\
\text { functions. Possible unique roles } \\
\text { in endothelial cells of capillaries } \\
\text { and eye (cornea and lens). } \\
\text { Absorption of } \mathrm{NH}_{3} \text { in rumen } \\
\text { and colon? }\end{array}$ \\
\hline CA III & 259 & Low $\left(\sim 1 \times 10^{4}\right)$ & Human $8 \mathrm{q} 22$ & $\begin{array}{l}\text { Mainly in red skeletal muscle } \\
\text { (type 1). Also in liver of non- } \\
\text { primates (esp. male rat), salivary } \\
\text { glands, smooth muscle (uterus), } \\
\text { red cells, prostate gland, lung, } \\
\text { kidney, brain colon, testis, } \\
\text { mammary gland, and white fat } \\
\text { cells }\end{array}$ & $\begin{array}{l}\text { Facilitation of } \mathrm{CO}_{2} \text { diffusion. } \\
\text { Role in muscle contraction? } \\
\text { Acid-base homeostasis (liver) }\end{array}$ \\
\hline $\begin{array}{l}\text { CA VII } \\
\text { Membrane-bound }\end{array}$ & 263 & $?$ & Human 16q21-23 & Salivary gland (?) & $?$ \\
\hline $\begin{array}{l}\text { CA IV } \\
\text { (glycoprotein) }\end{array}$ & $?$ & High & $?$ & $\begin{array}{l}\text { Lung (capillary endothelium), } \\
\text { kidney (brush border of tubular } \\
\text { cells). Probably also in other } \\
\text { tissues (e.g. muscle, liver, } \\
\text { gastrointestinal mucosa) }\end{array}$ & $\begin{array}{l}\text { Reabsorption of } \mathrm{HCO}_{3} \text { in } \\
\text { proximal renal tubules. } \\
\text { Transport of } \mathrm{H}^{+} \text {and } \mathrm{HCO}_{3}^{-} \text {in } \\
\text { capillary endothelium of lung, } \\
\text { and facilitation of } \mathrm{CO}_{2} \text { transfer, } \\
\mathrm{Ca}^{2+} \text { exchange (muscle)? }\end{array}$ \\
\hline \multicolumn{6}{|l|}{ Mitochondrial } \\
\hline CA V & $?$ & High & $?$ & $\begin{array}{l}\text { Kidney and liver. Probably in } \\
\text { many other tissues (e.g. muscle, } \\
\text { gastric mucosa) }\end{array}$ & $\begin{array}{l}\text { Provide } \mathrm{HCO}_{3}^{-} \text {for initial steps in } \\
\text { gluconeogenesis (e.g. liver \& } \\
\text { kidney), and ureagenesis (liver) }\end{array}$ \\
\hline \multicolumn{6}{|l|}{ Secreted } \\
\hline $\begin{array}{l}\text { CA VI } \\
\text { (glycoprotein }\end{array}$ & 314 & $\begin{array}{l}\text { High and } \\
\text { low }\end{array}$ & Human $1 \mathrm{pt} 36$ & Salivary glands (acinar cells) & Regulation of salivary $\mathrm{pH}$ ? \\
\hline \multicolumn{6}{|l|}{ Unknown } \\
\hline $\mathrm{CA} \cdot \mathrm{Y}$ ' & 262 & $?$ & $?$ & Mouse liver (possibly CA V) & $?$ \\
\hline \multicolumn{6}{|l|}{ Viral CA-like proteins } \\
\hline D8 product & 304 & - & - & $\begin{array}{l}\text { Vaccinia virus (transmembrane } \\
\text { protein) }\end{array}$ & $?$ \\
\hline $\begin{array}{l}\text { erb- } A \text { (domain 2) } \\
\text { product } \ddagger\end{array}$ & 164 & - & - & Avian erythroblastosis virus & $\begin{array}{l}\text { c-erb- } A \text { (thyroid hormone } \\
\text { receptor) }\end{array}$ \\
\hline
\end{tabular}

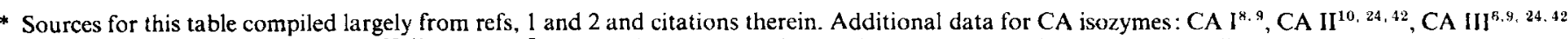
$\mathrm{CA}$ IV (W. S. Sly, unpublished), $\mathrm{CA} \mathrm{VI} \mathrm{I}^{37}, 41, \mathrm{CA} \mathrm{VIII}^{7}, \mathrm{CA}^{\prime} \mathrm{Y}^{\prime}$ is a tentative designation, sequence derived from mouse liver $\mathrm{mRNA}$ (M. Amor \& $\mathrm{T}$. Meo, unpublished). Viral sources: AEV erb-A, ${ }^{16,17}$ vaccinia $D 8^{14.15}$. $50 \%$ membrane-bound (rat). $\ddagger$ Homology to CA genes uncertain.

human CA II). The human CA I gene contains an unusually long $5^{\prime}$ noncoding region of about $37 \mathrm{~kb}$, making it about 3-5 times larger than the other CA genes. Because the evolutionary origin of the intron which interrupts this $5^{\prime}$ region is of interest, it will be useful to know to what extent it is also characteristic of the CA I genes from other, especially non-mammalian, sources.

The human CA I, CA II and CA III genes are linked on chromosome $8,{ }^{9.10}$ whereas the genes for CA VI and CA VII are located on chromosomes 1 and 16, respectively. ${ }^{71}$ Since the CA I, CA
II and CA III genes are present in birds and mammals, ${ }^{12}$ they must have been formed prior to the divergence of reptiles and mammals about 300 million years ago, and have remained linked in the mammalian lineage since that time. In view of the dispersion of the CA genes to at least three chromosomes, it 


\section{REVIEW ARTICLES}

TABLE II. Matrix comparing amino acid sequences of the carbonic anhydrases (CA) and CA-like proteins

\begin{tabular}{|c|c|c|c|c|c|c|c|c|}
\hline & CA II's & CA III's & CA VII & $\mathrm{CA}^{\prime} \mathrm{Y}^{\prime}$ & $\begin{array}{l}\text { D8 } \\
\text { (Vac- } \\
\text { cinia) }\end{array}$ & CA VI & CA IV & $\begin{array}{l}e r b-A \\
(A E V)\end{array}$ \\
\hline & \multicolumn{8}{|c|}{ Percent identity* } \\
\hline CA I's & 59 & 55 & 52 & 47 & 36 & 32 & 32 & 16 \\
\hline CA II's & - & 56 & 56 & 52 & 35 & 33 & 32 & 20 \\
\hline CA III's & - & - & 51 & 46 & 37 & 34 & 31 & 15 \\
\hline CA VII & - & - & $\ldots$ & 52 & 35 & 36 & 33 & 15 \\
\hline $\mathrm{CA}^{\prime} \mathrm{Y}^{\prime}$ & - & - & - & - & 34 & 34 & 32 & 17 \\
\hline D8 (vaccinia) & - & - & - & - & - & 29 & 29 & 13 \\
\hline CA VI & - & - & - & - & - & - & 28 & 15 \\
\hline CA IV & - & - & - & - & - & - & - & 9 \\
\hline
\end{tabular}

* Determined from arithmetic means of pairwise comparisons of 6 mammalian CA I's and CA II's, 5 CA III's, human CA IV and mouse CA ' $Y$ ', sheep CA VI, human CA VII, vaccinia D8, and human $c-e r b-A$. Sequences for CA I, CA II and CA III isozymes are from ref. 11 , plus mouse CA I ${ }^{38}$, mouse CA III (Y. Edwards, unpublished) and horse CA III $^{39}$. References for other sequences are: human CA VII, ${ }^{7}$ mouse CA ' $\mathrm{Y}$ ' (M. Amor \& T. Meo, unpublished), vaccinia virus D8 ${ }^{13}$ sheep $\mathrm{CA}$ VI, ${ }^{32}$ human CA IV (W. S. Sly \& C. X. L. Zhu, unpublished) and erb-A, domain $2 .^{16.17}$ Insertions and deletions were introduced to maximize the number of matches in the comparisons.

will now obviously be of interest to determine the chromosomal locations of the membrane-bound CA IV and mitochondrial CA $\mathrm{V}$ genes. Possibly, detailed analyses at the DNA level of the flanking regions of the CA I, II and III genes will eventually provide clues concerning the importance of common regulatory elements as selective factors in maintaining gene linkages. Preliminary studies in our laboratory indicate that in humans these genes are arranged in the $5^{\prime}$ to $3^{\prime}$ order (CA I, CA III, CA II) within a span of less than 180 kilobases (P. J. Venta, unpublished, and ref. 13).

Although the structures of CA genes from plants and lower organisms have not been characterized, it is interesting to note that a CA-like gene (D8), devoid of introns, and encoding 304 amino acids, has been found in vaccinia virus. ${ }^{14}$ When the derived amino acid sequence is compared to the sequences of the cellular CA isozymes, the percent identity ranges from $37 \%$ to $29 \%$ (Table II). This viral gene product, however, probably lacks CA activity (see discussion of active sites below). Recent studies have demonstrated that the product of the D8 gene is a transmembrane protein with a major extraviral, CA-like domain which is non-essential for viral propagation. ${ }^{15} \mathrm{It}$ will be especially interesting to dissect the evolutionary history of the vaccinia D8 gene by examining other pox viruses. Another virus which possibly contains a CA-related gene is avian erythroblastosis virus (AEV), ${ }^{16}$ in which the $3^{\prime}$ portion (domain 2) of its erb- $A$ gene may be homologous to a region spanning residues 10-183 (based on CA I numbering) ${ }^{12}$ of the 261 residues characteristic of the CA I, CA II and CA III isozymes. ${ }^{12}$ It is now known that the human and chicken cellular c-erb- $A$ gene encodes a thyroid hormone receptor, ${ }^{17}$ the C-terminal, hormone-binding segment of which shows some apparent similarity (not statistically significant) to the region (positions 10-183) of the CA sequences just discussed. Thus, c-er $b-A$ may be a hybrid gene deriving its $3^{\prime}$ hormone-binding half from a portion of a CA gene, and its $5^{\prime}$ DNA-binding region from some other source.

\section{Phylogenetic Relationships}

To date, amino acid séquences have been determined, or inferred from DNA sequences, for the CA I, CA II and CA III isozymes from a number of species, ${ }^{12}$ as well as sequences from single species for the more recently characterized CA isozymes, CA VI, CA VII and CA ' $\mathrm{Y}$ '. $\mathrm{CA}^{\text {' }} \mathrm{Y}$ ' is a tentative designation for a $\mathrm{CA}$ isozyme whose sequence was derived from mouse-liver mRNA (M. Amor \& T. Meo, unpublished). Because its sequence does not closely resemble any of the other mouse CA isozymes (Table III), it is possible that it represents the mitochondrial isozyme, CA V (see below).

A matrix has been prepared comparing the consensus amino acid sequences for CA I, CA II and CA III, along with those for CA IV, CA VI, CA VII, $C A$ ' $\mathrm{Y}$ ' and the two viral CA-like genes (Table II). As can be seen, there is a $59 \%$ percent identity between the CA I and CA II sequences, with an apparent decrease in evolutionary relatedness when comparisons are made with other CA and CA-like sequences in the order:

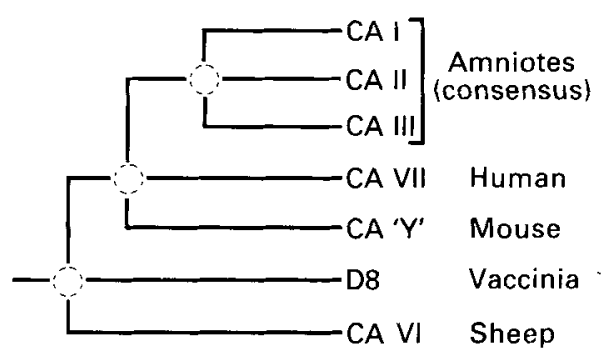

Fig. 1. Generalized phylogenetic branching scheme for the $C A$ isozymes of amniotes and the vaccinia D8 protein. Based on amino acid sequences cited in Table II.

CA III, CA VII, CA 'Y', vaccinia D8, CA VI, CA IV and $e r b-A$. With the exception of the latter two, these CA and CA-related sequences were also used to construct the generalized branching scheme shown in Fig. 1 utilizing a maximum parsimony algorithm for determining ancestral sequences. ${ }^{12}$ As shown with the matrix analysis, there is a similar order of evolutionary relatedness of the CA genes, with the salivary CA VI gene appearing to have diverged first from the ancestral root.

\section{The Active Sites}

Because the three-dimensional structures of human CA I and CA II and bovine CA III have been determined, ${ }^{18,19}$ it is possible to compare residues presumed to be located within the active sites of the different CA isozymes (Table III). Of the 36 residues at homologous positions, $17(47 \%)$ are invariant. Of the other residues, all expect the tiger shark red-cell $\mathrm{CA}$ have at least one residue that seems to be unique and invariant for that isozyme. To what extent these residues contribute to the catalytic variation noted among the different isozymes is difficult to assess. For example, CA III is a lowactivity isozyme which is not strongly inhibited by sulfonamides, ${ }^{20}$ and it is tempting to attribute these feature to one or more of its eight unique residues, especially the basic residues, Arg and Lys, at positions 64, 67 and 91. However, when His-64 was replaced by Lys in human CA II by site-directed mutagenesis, no appreciable reduction in its $\mathrm{CO}_{2}$ hydrase activity at $\mathrm{pH} 8.8$ was observed. ${ }^{21}$ This was unexpected, because His-64 was thought to play an important role in the transfer of protons from the active site in the interconversion of $\mathrm{CO}_{2}$ and $\mathrm{HCO}_{3}{ }^{-22}$ Another possibility is that the unique Phe198 residue may modify the function of the Thr-199/Glu-106 complex which has been strongly implicated in the catalytic process. $^{22}$ Also, the unique 
Residue number

\begin{tabular}{|c|c|c|c|c|c|c|c|c|c|c|c|c|c|c|c|c|c|c|c|c|c|c|c|c|c|c|c|c|c|c|c|c|c|c|c|c|c|c|}
\hline & & & & & & & & & & & & & & & & 1 & 1 & 1 & 1 & 1 & 1 & 1 & 1 & 1 & 1 & 1 & 1 & 1 & 2 & 2 & 2 & 2 & 2 & 2 & 2 & 2 & 2 & 2 \\
\hline & & & & 2 & 6 & 6 & 6 & 6 & 6 & 6 & 6 & 9 & 9 & 9 & 9 & 0 & 0 & 1 & 1 & 2 & 3 & 4 & 4 & 4 & 9 & 9 & 9 & 9 & 0 & 0 & 0 & 0 & 0 & 0 & 0 & 1 & 4 & 4 \\
\hline CA Forn & $\mathrm{ms}^{\mathrm{c}}$ & & 7 & 9 & 1 & 2 & 4 & 5 & 6 & 7 & 9 & 1 & 2 & 4 & 6 & 6 & 7 & 7 & 9 & 1 & 1 & 1 & 3 & 5 & 2 & 4 & 8 & 9 & 0 & 1 & 2 & 4 & 6 & 7 & 9 & 1 & 4 & 6 \\
\hline & & & $*$ & $*$ & & & $*$ & & & $\star$ & & & $*$ & $\mathrm{Zn}$ & $\mathrm{Zn}_{\mathrm{n}}$ & $*$ & $*$ & $*$ & $\mathrm{Zn}$ & & & & & & & $\dot{x}$ & & $*$ & $*$ & & & & & & $\dot{*}$ & & $*$ & $*$ \\
\hline Human & CA & $\mathrm{I}$ & $\bar{Y}$ & S & $\mathrm{N}$ & V & $\mathrm{H}$ & $S$ & $F$ & $\mathrm{H}$ & $\mathrm{N}$ & F & $Q$ & $\mathrm{H}$ & $\mathrm{H}$ & $\bar{E}$ & $\mathrm{H}$ & $\bar{E}$ & $\mathrm{H}$ & A & L & L & V & G & $W$ & $\mathrm{Y}$ & L & $\mathrm{T}$ & $\mathrm{H}$ & $\mathrm{P}$ & $\mathrm{P}$ & $Y$ & $\mathrm{~S}$ & V & W & I & $\bar{N}$ & $R$ \\
\hline Rabbit & $\mathrm{CA}$ & I & $Y$ & $S$ & $\mathbf{N}$ & V & $\mathrm{H}$ & $S$ & $\mathrm{~F}$ & $\mathrm{H}$ & N & $S$ & $Q$ & H & $\mathbf{H}$ & $\mathrm{E}$ & $\mathrm{H}$ & $\mathrm{E}$ & $\mathrm{H}$ & $\mathrm{V}$ & I & L & I & A & W & $\mathrm{Y}$ & $\mathbf{L}$ & $\mathrm{T}$ & $\mathrm{H}$ & $p$ & $P$ & $\mathrm{H}$ & $\mathrm{S}$ & V & $W$ & I & $\mathrm{N}$ & $\mathrm{R}$ \\
\hline Mouse & $\mathrm{CA}$ & I & $Y$ & $S$ & $\mathrm{~N}$ & V & $\mathrm{H}$ & $S$ & $\mathrm{~F}$ & H & I & $\mathrm{T}$ & $Q$ & $\mathrm{H}$ & $\mathrm{H}$ & $\mathrm{E}$ & $\mathrm{H}$ & $E$ & $\mathrm{H}$ & V & A & L & I & G & $\mathrm{W}$ & $\mathrm{Y}$ & $\mathrm{L}$ & $\mathrm{T}$ & $\mathrm{H}$ & P & $\mathrm{P}$ & $\mathrm{H}$ & $S$ & V & $W$ & I & $\mathrm{N}$ & $\mathrm{R}$ \\
\hline $\mathrm{Ox}$ & $\mathrm{CA}$ & I & $\mathrm{Y}$ & $S$ & $\mathrm{~N}$ & V & $\mathrm{H}$ & $\mathrm{S}$ & $F$ & $\mathrm{H}$ & $\mathrm{N}$ & $\mathrm{F}$ & $Q$ & $\mathbf{H}$ & $\mathrm{H}$ & $\mathrm{E}$ & $\mathrm{H}$ & E & $\mathrm{H}$ & v & $\mathrm{F}$ & L & $L_{t}$ & G & W & $Y$ & $\mathrm{~L}$ & $\mathrm{~T}$ & $\mathrm{H}$ & $P$ & $\mathrm{P}$ & $\mathrm{L}$ & $\mathrm{S}$ & V & $W$ & I & $\mathrm{N}$ & $\mathrm{R}$ \\
\hline Horse & $\mathrm{CA}$ & I & $Y$ & $S$ & $\mathrm{~N}$ & V & $\mathrm{H}$ & S & $\mathrm{F}$ & Q & K & V & $Q$ & $\mathrm{H}$ & $\mathrm{H}$ & $\mathrm{E}$ & $\mathrm{H}$ & $\mathrm{E}$ & $\mathrm{H}$ & V & F & $\mathrm{L}$ & I & G & $\mathrm{W}$ & $Y$ & L & $\mathrm{T}$ & $\mathrm{H}$ & $P$ & $P$ & $Y$ & $\mathrm{~S}$ & V & $\mathrm{W}$ & V & $\mathrm{N}$ & $\mathrm{R}$ \\
\hline Turtle & CA & I & $Y$ & $S$ & $\mathrm{~N}$ & V & $\mathrm{H}$ & $\mathrm{S}$ & $F$ & $\mathrm{H}$ & $\mathrm{N}$ & $Q$ & $Q$ & $\mathrm{H}$ & $\mathrm{H}$ & E & $\mathrm{H}$ & $E$ & $\mathrm{H}$ & V & $\mathrm{F}$ & $L$ & L & G & $W$ & $Y$ & L. & $\mathrm{T}$ & $\mathrm{H}$ & $P$ & $\mathbf{P}$ & F & $\mathrm{S}$ & V & $W$ & $I$ & $\mathrm{~N}$ & $\mathrm{R}$ \\
\hline Human & $\mathrm{CA}$ & I I & $\mathrm{Y}$ & $S$ & $\mathrm{~N}$ & $\mathrm{~N}$ & $\mathrm{H}$ & A & $\mathbf{F}$ & N & $E$ & I & $Q$ & $\mathbf{H}$ & $\mathbf{H}$ & E & $\mathrm{H}$ & $E$ & H & v. & $F$ & L & V & G & W & $y$ & L. & $\mathrm{T}$ & $\mathrm{T}$ & $P$ & $\mathbf{P}$ & L & C & V & $\mathrm{w}$ & V & $\mathrm{N}$ & $\mathrm{R}$ \\
\hline Rabbit & $\mathrm{CA}$ & I I & $Y$ & $S$ & $\mathrm{~N}$ & $\mathrm{~N}$ & $\mathrm{H}$ & $\mathrm{S}$ & $F$ & $\mathrm{~N}$ & E & I & $Q$ & $\mathrm{H}$ & H & $\mathrm{E}$ & H & $\mathrm{E}$ & $\mathrm{H}$ & v & $\mathrm{F}$ & I & V & G & $W$ & $Y$ & $\mathrm{~L}$ & $\mathrm{~T}$ & $\mathrm{~T}$ & $P$ & $\mathrm{P}$ & L & C & V & $w$ & V & $\mathrm{N}$ & $\mathrm{R}$ \\
\hline Mouse & $\mathrm{CA}$ & II & $Y$ & S & $\mathrm{N}$ & $\mathrm{N}$ & $\mathrm{H}$ & $S$ & $F$ & $\mathrm{~N}$ & E & $\mathrm{v}$ & $Q$ & $\mathrm{H}$ & $\mathrm{H}$ & $\mathrm{E}$ & $\mathrm{H}$ & E & $\mathrm{H}$ & V & $F$ & L & v & G & $\mathrm{W}$ & $Y$ & $\mathrm{~L}$ & $\mathrm{~T}$ & $\mathrm{~T}$ & $\mathrm{P}$ & $\mathrm{P}$ & L & C & v & $w$ & V & $\mathrm{N}$ & $\mathbf{R}$ \\
\hline$O x$ & $\mathrm{CA}$ & II & $Y$ & $S$ & $\mathrm{~N}$ & $\mathrm{~N}$ & $\mathrm{H}$ & $S$ & $\mathbf{F}$ & $\mathrm{N}$ & $E$ & I & $Q$ & $\mathrm{H}$ & $\mathrm{H}$ & E & $\mathrm{H}$ & $E$ & $\mathrm{H}$ & V & $F$ & L & V & G & W & $Y$ & $\mathrm{~L}$ & $\mathrm{~T}$ & $T$ & $P$ & $\mathrm{P}$ & L & $S$ & V & W & V & $\mathrm{N}$ & $\mathbf{R}$ \\
\hline Horse & $\mathrm{CA}$ & II & $Y$ & $S$ & $\mathrm{~N}$ & $\mathrm{~N}$ & $\mathrm{H}$ & $S$ & $\mathrm{~F}$ & $\mathrm{~N}$ & $E$ & I & $Q$ & $\mathrm{H}$ & $\mathrm{H}$ & E & $\mathrm{H}$ & $E$ & $\mathrm{H}$ & $\mathrm{V}$ & F & L & V & G & $\mathrm{W}$ & $\mathrm{y}$ & L & $\mathrm{T}$ & $\mathbf{T}$ & $P$ & p & L & C & V & $w$ & $\mathrm{~V}$ & $\mathrm{~N}$ & $\mathrm{R}$ \\
\hline Chick & $\mathrm{CA}$ & I I & $Y$ & $S$ & $\mathrm{~N}$ & $N$ & $\mathrm{H}$ & $S$ & $F$ & $N$ & $E$ & V & $Q$ & $\mathrm{H}$ & $\mathrm{H}$ & $E$ & H & $E$ & $\mathrm{H}$ & V & $F$ & I & v & $\mathrm{G}$ & $\mathrm{W}$ & $Y$ & L & $\mathrm{T}$ & $T$ & P & $\mathbf{P}$ & $\mathrm{H}$ & C & v & W & $\mathrm{V}$ & $\mathrm{N}$ & R \\
\hline Human & $\mathrm{GA}$ & III & $Y$ & $S$ & $\mathbf{N}$ & $\mathrm{N}$ & $i \mathrm{~K}$ & $T$ & C & $\mathbf{R}$ & $v$ & $R$ & $Q$ & $\mathrm{H}$ & $\mathrm{H}$ & $\mathrm{E}$ & $\mathrm{H}$ & $E$ & $\mathrm{H}$ & $V$ & $F$ & II & $\mathrm{V}$ & G & $W$ & $Y$ & $F$ & $\mathrm{~T}$ & $T$ & $P$ & $\mathrm{P}$ & $E$ & $C$ & $I$ & $w$ & $L$ & $\mathrm{~N}$ & R \\
\hline Mouse & $\mathrm{CA}$ & III & $Y$ & $S$ & $\mathrm{~N}$ & $\mathrm{~N}$ & ${ }^{\prime} R_{1}$ & $T$ & C & $\mathrm{R}$ & $\mathrm{v}$ & $\mathrm{R}$ & $Q$ & $\mathrm{H}$ & $\mathrm{H}$ & $E$ & $\mathrm{H}$ & $E$ & $\mathrm{H}$ & V & $F$ & $I$ & V & G & W & $Y$ & $F$ & $\mathrm{~T}$ & $\mathrm{~T}$ & $P$ & P & $E$ & C & I & W & $\mathrm{L}$ & $\mathrm{N}$ & $\mathrm{R}$ \\
\hline $\mathrm{Ox}$ & $\mathrm{CA}$ & II I & $Y$ & s & $N$ & $\mathrm{~N}$ & I KI & $T$ & C & $\mathrm{R}$ & V & $R$ & $Q$ & $\mathrm{H}$ & $\mathrm{H}$ & $E$ & $\mathrm{H}$ & $E$ & $\mathrm{H}$ & V & $F$ & $I$ & V & G & $W$ & $Y$ & $\mathrm{~F}$ & $\mathrm{~T}$ & $\mathrm{~T}$ & $p$ & $\mathrm{P}$ & E & C & I & w & L. & $\mathrm{N}$ & $\mathrm{R}$ \\
\hline Horse & $C A$ & III & $Y$ & $S$ & $N$ & $\mathrm{~N}$ & IR! & $T$ & $c$ & $\mathrm{R}$ & V & $\mathrm{R}$ & $Q$ & $\mathrm{H}$ & H & $E$ & $\mathrm{H}$ & $E$ & $\mathrm{H}$ & V & $\mathrm{Y}$ & II & V & G & $W$ & $Y$ & $\mathrm{~F}$ & $T$ & $\mathrm{~T}$ & $\mathrm{P}$ & $\mathbf{P}$ & $E$ & $c$ & I & $w$ & $L$ & $\mathrm{~N}$ & R \\
\hline Shark & $\mathrm{CA}$ & & $x$ & $s$ & $X$ & $X$ & $x$ & $x$ & $x$ & $x$ & $\mathrm{X}$ & $R$ & $Q$ & $\mathbf{H}$ & $\mathrm{H}$ & $\mathrm{E}$ & $\mathrm{H}$ & $E$ & $\mathrm{H}$ & V & $F$ & L & $\mathrm{v}$ & G & $W$ & $Y$ & $\mathrm{~L}$ & $T$ & $T$ & $p$ & $P$ & L & $S$ & V & W & V & $N$ & $\mathrm{R}$ \\
\hline Mouse & $\mathrm{CA}$ & "Y" & $x$ & $S$ & $N$ & $\mathrm{~V}$ & $\mathrm{H}$ & Q & $\mathrm{F}$ & $Q$ & V & $K$ & $Q$ & $\mathrm{H}$ & H & $\mathrm{E}$ & $\mathrm{H}$ & $E$ & $\mathrm{H}$ & $F$ & $Y$ & $L$ & V & G & $W$ & $Y$ & $L$ & $\mathrm{~T}$ & $\mathrm{~T}$ & $P$ & P & A & $S$ & V & w & $\mathrm{V}$ & $\mathrm{N}$ & $R$ \\
\hline Human & $\mathrm{CA}$ & VI I & $Y$ & $S$ & $\mathrm{~N}$ & $\mathrm{~N}$ & $\mathrm{H}$ & $S$ & V & $Q$ & D & $\mathrm{K}$ & $Q$ & $\mathrm{H}$ & H & $E$ & $\mathrm{H}$ & $E$ & $\mathrm{H}$ & $\mathrm{V}$ & $F$ & L & V & G & $\mathrm{W}$ & $Y$ & L & $\mathrm{T}$ & $\mathrm{T}$ & $\mathrm{P}$ & $P$ & $\mathrm{~S}$ & $\mathrm{~N}$ & V & $W$ & V & $\mathrm{N}$ & $\mathrm{R}$ \\
\hline Sheep & $\mathrm{CA}$ & $V_{I}$ & $Y$ & $S$ & $\mathbf{N}$ & $\mathrm{N}$ & $\mathrm{H}$ & $T$ & V & $\mathbf{N}$ & $S$ & K & $Q$ & $\mathrm{H}$ & H & $E$ & $\mathrm{H}$ & $\mathrm{E}$ & $\mathrm{H}$ & V & $\mathrm{Y}$ & L & V & A & 1 & $Y$ & $\mathrm{~L}$ & $\mathrm{~T}$ & $\mathrm{~T}$ & $P$ & $P$ & $\mathrm{~T}$ & $N$ & V & $W$ & V & $N$ & R \\
\hline Human & $\mathrm{CA}$ & $V_{I}$ & $\mathrm{Y}$ & $\mathrm{S}$ & $N$ & $\mathrm{~N}$ & $\mathrm{H}$ & $\mathrm{T}$ & V & $Q$ & G & $Q$ & $Q$ & $\mathrm{H}$ & $\mathrm{H}$ & $E$ & $\mathrm{H}$ & $\mathrm{E}$ & $\mathrm{H}$ & V & $\mathrm{Y}$ & $\mathrm{L}$ & V & A & $\mathrm{Y}$ & $Y$ & $\mathrm{~L}$ & $\mathrm{~T}$ & $\mathrm{~T}$ & $p$ & $P$ & $\mathrm{~T}$ & $\mathrm{~N}$ & v & $\mathrm{W}$ & V & $\mathrm{N}$ & $\mathrm{R}$ \\
\hline Vaccini & & D8 & & $S$ & $\mathrm{~N}$ & $\mathrm{~T}$ & K & L. & V & $\mathrm{R}$ & $\mathrm{N}$ & $S$ & 3 & $\mathrm{H}$ & $\mathrm{Y}$ & 19 & $\mathrm{~N}$ & E & $\mathrm{N}$ & $\mathrm{V}$ & $\mathrm{Y}$ & $\mathrm{L}$ & I & $S$ & F & $Y$ & - & $\mathrm{T}$ & $T$ & I & $\mathrm{N}$ & $S$ & $\mathrm{D}$ & A & W & I & $\mathrm{N}$ & $\mathrm{R}$ \\
\hline
\end{tabular}

a Based on tertiary structures of human CA I, CA II and bovine CA I1I. ${ }^{17,10}$

Based on CA I numbering. ${ }^{12}$

Sequence sources are as in legend for Table II. Tiger-shark sequence from N. Berhenhem \& U. Carlsson (unpublished). Residues common to all animal sequences (including vaccinia) have been boxed. Other boxes indicate invariant and unique residues for CA isozymes of aminiotes. Dashed box at position 64 for CA IIl's indicates unique basic residues. Residues forming hydrogen-bond network to Zn-bound solvent molecule, or to the three Zn-liganded His residues (designated, $\mathrm{Zn}$ ), in human CA I and CA II and bovine CA III (cf. refs. 17, 18) are designated by an asterisk (*).

Cys-66 residue could conceivably contribute to the characteristic properties of the CA III isozymes. Almost certainly, results from other site-directed mutageneis studies will provide further insights into the active site mechanisms of the CA isozymes.

The antiquity of the active-site structure is suggested by an examination of the residues found in the red-cell CA of the tiger shark (Table III), a cartilaginous fish which arose around 450 million years ago. Although the residues at positions 64-69 have not been determined, the shark $\mathrm{CA}$ has retained an active-site structure differing little from those of the cystolic CA isozymes of amniotes. However, since this represents the first structure of a nonamniotic CA, it would be premature to say that the active-site residues of the shark CA are representative of the ancestral structure.

Unfortunately, no clues are evident concerning the evolution of the active sites by simply examining the structural regions coded by exons. As shown in Table III and Fig. 2, residues associated with the active sites are coded on all but one exon, and the three His residues binding the essential zinc ion are coded on exons 2 and 3 . In view of the observations from several studies that exons encode various domains of proteins, it is notable that no similar correlation is evident when the exonic regions of mammalian and avian CA II genes are compared with the structural or functional features of the CA II molecules (Fig. 2).

It is also noteworthy that the CArelated gene, $\mathrm{D} 8$, from the vaccina virus has retained $60 \%$ of the active site residues found in the cellular $\mathrm{CA}$ isozymes (Table III). However, because certain crucial residues are not present, such as the zinc-binding His residues at positions 96 and 119 , the possibility that this viral protein has CA activity is extremely remote.

\section{Hormonal and Neuronal Control}

Early studies indicated that the activities or levels of CA I and CA II in various mammalian tissues could be influenced by thyroxine (red blood cells), sex hormones (endometrium, accessory sex glands), cyclic AMP-mediated action of epinephrine (red blood cells), and prolactin (pituitary gland). ${ }^{3}$

Recently, it was shown that pituitary growth hormone $(\mathrm{GH})$ has a differential effect on the levels of CA III in rat liver, where the amount of CA III in the male can be 15-20 times greater than in the female. ${ }^{23}$ Initially, this was thought to be due to the induction of CA III by testosterone; however, recent studies indicate that CA III is suppressed in the female liver by the continuous action of GH, whereas the pulsatory release of $\mathrm{GH}$ in the male does not noticeably suppress the levels of CA III. ${ }^{23}$ No similar effect of GH on CA III was seen in muscle where the levels of CA III are the same in males and females. It is noteworthy that CA III (as well as CA II) in rat liver as determined by immunofluorescence is concentrated in hepatocytes surrounding the central vein. ${ }^{24}$ In these perivenous cells, the staining intensity of CA III is markedly higher in males than in females, whereas the 


\section{REVIEW ARTICLES}

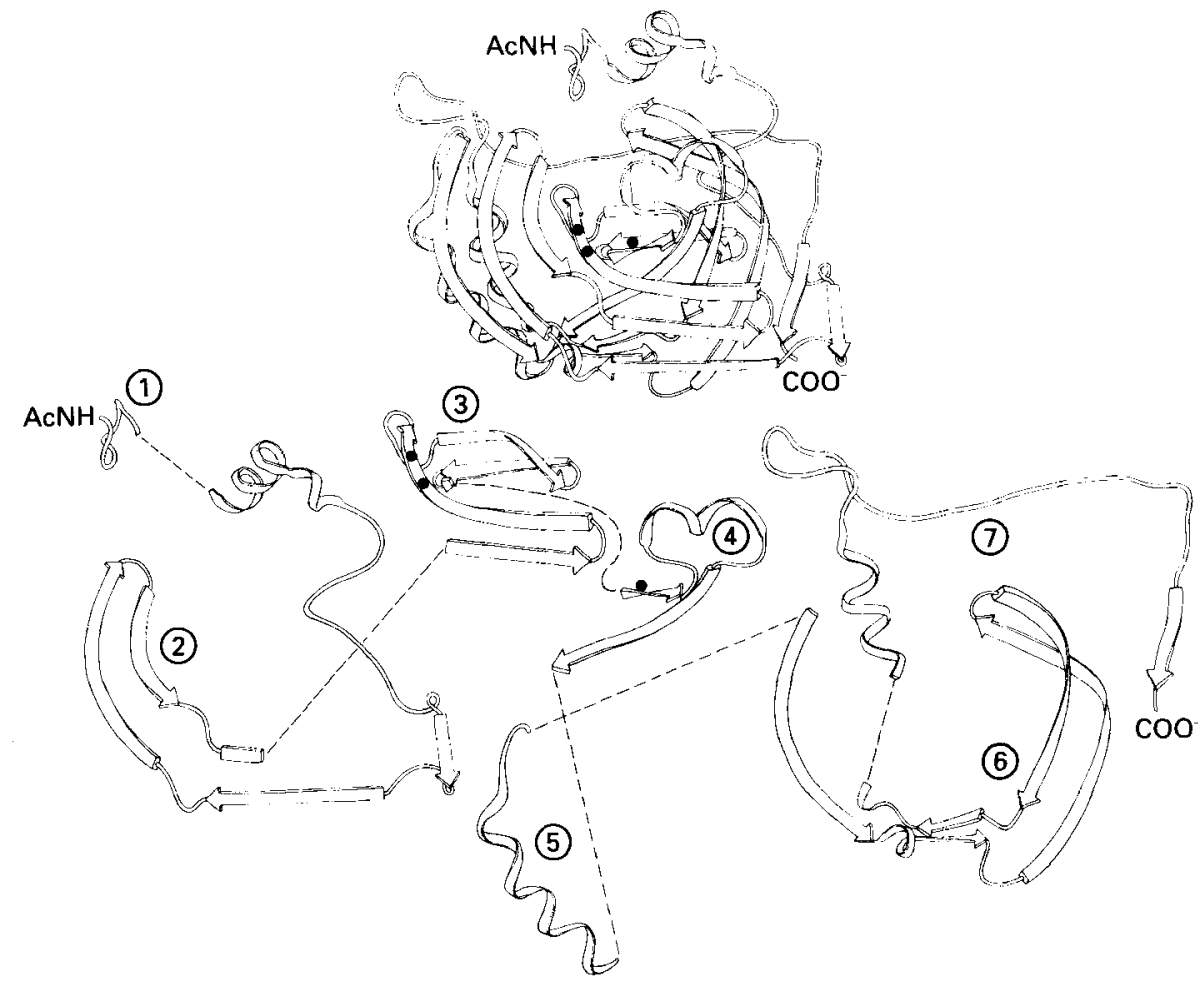

Fig. 2. Schematic representation of the three-dimensional structure of human carbonic anhydrase II (above), and separated structures of the segments encoded by the seven exons of human and mouse CA II genes (below). Beta strands are designated by arrows. Based on the human $C A$ I sequence ${ }^{12}$ the numbering of the residues encoded by these exans are: exon 1 (residues 1 12), exon 2 (12 78), exon 3 (78-117), exon 4 (118-149), exon 5 (150-170), exon 6 (171 222) and exon 7 (223-260). The His residues at 94, 96 and 119 forming ligands to the active-site $Z n$ ion are indicated by solid circles $(O)$. The tertiary structure of CA II is based on Fig. 3 in ref. 22 originally drawn by Anders Liljas.

opposite is true for CA II, which stains more intensely in females than in males.

Changes in the levels of CA III in rat skeletal muscle brought about by hypoand hyperthyroid conditions seem to depend on the type and amounts of the different fibers. The increase in CA III resulting from thyroidectomy was due not only to an increase in the slowtwitch type-1 fibers (which normally express CA III), but also in a subtype of type $2 \mathrm{~A}$ fibers (which do not normally express CA III). ${ }^{25}$ Treatment with thyroid hormone brought about a decrease of CA III in type-1 fibers, and an increase in CA III in type $2 \mathrm{~A}$ fibers. ${ }^{26}$ These variations in the expression of CA III in the different fiber types to varying thyroxine levels are difficult to interpret at present. It is of interest that a similar response to thyroxine levels has been noted for CA I in human and mouse red cells in that hyper- and hypothyroidism results in increased and decreased levels, respectively, of CA I. ${ }^{3}$

Neuronal control of CA III in rat and rabbit skeletal muscle has also been shown by the demonstration of increased levels of CA III after denervation, ${ }^{27}$ or the continuous stimulation of an innervating nerve. ${ }^{20}$ Interestingly, the elevated levels are more pronounced established. Thus it is the simple reversible hydration of $\mathrm{H}^{+}$and $\mathrm{HCO}_{3}^{-}$ from $\mathrm{CO}_{2}$ and $\mathrm{H}_{2} \mathrm{O}$ which is the basis for the numerous putative and established physiological roles of the CA isozymes (Table I). This functional diversity appears to be mostly associated with the widely distributed highactivity CA II isozyme and to some extent with CA I. Although CA III is found mainly in skeletal muscle, it is also expressed in hepatocytes (as discussed above) and at low levels in certain other cells. In muscle, CA III has been implicated in the facilitated transport of $\mathrm{CO}_{2},{ }^{20}$ and is also thought to have a role in the slow-twitch contractile apparatus of type-1 fibers. ${ }^{26}$ CA III does not seem to be associated with any subcellular structures of the muscle cell such as mitochondria, nuclei, triads and $Z$ and $M$ bands. ${ }^{30}$ It is difficult to understand why the low-activity CA III isozyme is needed in muscle and liver; however, because CA III possesses low acid phosphatase activity, it is possible that it may function in a role different from, or in addition to, that of facilitating $\mathrm{CO}_{2}$ diffusion. ${ }^{20}$ The clustering of CA II and CA III around the venous wall in liver suggests that the acidsecreting hepatocytes regulate protein and $\mathrm{HCO}_{3}^{-}$secretion into the blood, implicating a role in acid-base balance. ${ }^{2}$ The other isozymes (CA IV, CA V, CA VI and CA VII) seem to be more restricted in their cellular or subcellular expression. Although the membranebound CA IV form is known to occur in kidney (brush border of luminal cells) and lung (endothelium), it seems likely that it will be found in other tissues as well. As of now, the greatest number of expressed $\mathrm{CA}$ genes that have been reported are apparently expressed in the salivary glands. These are: the cytosolic CA I, CA II and CA III forms, the secreted CA VI form, and the newly discovered isozyme CA VII, ${ }^{7}$ previously designated $\mathrm{CA}$ ' $\mathrm{Z}$ ' (Table I). Why are four, non-secreted, cytosolic forms of CA needed to carry out their putative roles in fluid and ion transport? Of course, a similar question can be asked about the roles of the same CA I, II and III isozymes in such tissues as liver and muscle, which incidentally probably also express a total of at least five $\mathrm{CA}$ genes.

\section{Diversity in Expression and Function}

Although the CA isozymes are known to possess activities other than the reversible hydration of $\mathrm{CO}_{2}$ (e.g. carboxylesterase, aldehyde hydratase, phosphatase), ${ }^{3}$ physiological roles, if any, for these activities have not been

\section{Metabolic Roles}

The presence of carbonic anhydrase in liver mitochondria has been confirmed in guinea pig and rat, and more recently reported from the mitochondria of rat 
REVIEW ARTICLES

(but not guinea pig) kidney. ${ }^{19,31}$ It also may be present in the mitochondria of muscle fibers, oligodendrocytes, and gastric mucosa. The partial amino acid sequence of a CA isozyme (termed CA $\mathrm{V})$ purified from guinea-pig mitochondria has been reported, ${ }^{32}$ and an examination of the sequence indicates that it is coded by a CA gene distinct from those coding for the other CA isozymes.

Because CA inhibitors (e.g. acetazolamide) diminish the production of urea and glucose in hepatocytes, it appears that a role for $\mathrm{CA} \mathrm{V}$ in mitochondria (which are permeable to $\mathrm{CO}_{2}$, but not $\mathrm{HCO}_{3}{ }^{-}$), is to provide $\mathrm{HCO}_{3}{ }^{-}$ions for the synthesis of carbamyl phosphate and oxaloacetate formed in the first, intramitochondrial steps, respectively, of the urea cycle and gluconeogenesis. Possible roles for mitochondrial CA in muscle, brain and gastric mucosa have yet to be fully explored.

In addition, the production of $\mathrm{HCO}_{3}^{-}$ by $\mathrm{CA}$ is probably utilized for other anabolic syntheses requiring carboxylation reactions such as fatty-acid synthesis as well as the synthesis of certain amino acids. ${ }^{33}$

\section{Inferring Function from Carbonic Anhydrase Deficiencies}

We might expect to learn something about function of an enzyme if its absence results in an abnormality in the cell or tissue where it is normally expressed. Therefore it was somewhat unexpected to find that the inherited deficiency of CA I in humans and pigtail macaques (homozygous for the deficiency gene) produced no detectable defect. $^{3}$ Although seemingly not as widely distributed as the CA II isozyme, CA I is nevertheless the second most abundant protein in red cells next to hemoglobin, and is found in the cells of a number of different tissues (Table I). Among the mechanisms which could compensate for the loss of the CA I activity would be that CA II is probably present in most cells where CA I is expressed and could substitute for the role of CA I. Because individuals deficient in CA I exhibit no detectable clinical symptoms on routine physical examination, nothing was learned about any specific function of CA I. On the other hand, a deficiency of CA II in humans was more informative, as its pleiotropic effects include impairments to growth, kidney function, bone resorption, and brain development. ${ }^{34}$ Even this was not anticipated, because the wide distribution of CA II (Table I) would suggest that its deficiency would result in a syndrome of even greater severity. Again, as in the CA I deficiency, the presence of CA I or other CA isozymes in a cell deficient in CA II probably compensates for the absence of CA II. This was nicely demonstrated in studies on intact erythrocytes from humans deficient in CA II, where the CA I isozyme which is normally present at high levels appears to function quite adequately in carrying out the important respiratory role of $\mathrm{CA}$ in the red cell. ${ }^{35}$ In all likelihood, alternative biochemical pathways or mechanisms compensate for the loss of CA II in those cells. With this in mind, we might speculate on the consequences of deficiencies in the non-cytoplasmic CA isozymes such as the membrane-bound CA IV and mitochondrial CA V forms, where the probability of a 'back-up' CA seems less likely. Possibly, CA V deficiency would result in hyperamoniaemia, and the absence of CA IV would produce critical dysfunctions in kidney and lung.

An important finding from studies on the human CA II-deficiency syndrome was that the osteopetrosis produced by a reduction in bone demineralization confirmed that the CA II normally present in osteoclasts is involved in bone resorption. However, osteopetrosis was not observed in mice deficient in CA II, ${ }^{36}$ although CA II is known to be expressed in murine osteoclasts.

So far as kidney function is concerned, the renal tubular acidosis appears to be produced by an impairment of renal acidification and $\mathrm{HCO}_{3}^{-}$reabsorption in both CA II-deficient humans and mice, and is probably due to the absence of soluble CA II in the luminal cells of the distal and proximal tubules, which impedes the reclamation of $\mathrm{HCO}_{3}{ }^{-}$.

The cerebral calcification associated with humans deficient in CA II has not been observed in CA II-deficient mice. However, older CA II-deficient mice do exhibit calcified plaques in the choroid plexus, in addition to rather extensive medial calcification of small arteries in a number of organs ${ }^{40}$. Whether the cerebral calcification found in older CAII-deficient humans arises from vascular calcinosis has yet to be determined. CA II appears to be the most prevalent $\mathrm{CA}$ isozyme in brain and is characteristically found in oligodendrocytes. The association between CA II deficiency and mental impairment in humans is not understood. Although some degree of mental impairment is usually associated with the CA II-deficiency syndrome, some affected individuals have been reported with seemingly normal mental function in spite of extensive cerebral calcification $^{34}$.

The differences in the pleiotropic human and mouse phenotypes serve as a warning that species-specific CA isozyme expression, and differences in interacting gene products, may compromise the general use of animal models.

As yet the molecular lesions responsible for the human and mouse CA deficiencies have not been determined. In the mice deficient in CA II the levels of CA II mRNA were not found to deviate from normal in all tissues examined, including brain and kidney, suggesting that a translational defect is responsible for the deficiency. No major deletion in the CA II gene from CA IIdeficient humans was detected by Southern blot analysis, and although a considerable portion of the defective genes found in patients from Belgium and Kuwait $^{34}$ has been sequenced in our laboratory, no splicing or coding errors, or alternations in the promoter regions, have as yet been detected (P. J. Venta, unpublished).

Finally, with regard to the control of gene expression, several features of the inherited CA deficiencies might be expected to repay detailed analyses at the DNA level. One of the most intriguing is that the reduction of red-cell CA I to trace levels in pigtail macaques deficient in $\mathrm{CA} \mathrm{I}$ is accompanied by a $60 \%$ reduction in the closely linked CA II gene product..$^{3.13}$ It would obviously be of considerable interest to determine the molecular defect responsible for this 'double deficiency' such as the possibility of a mutation in a common regulatory cis-element. Another type of 'double deficiency' is the possibility of trans-acting regulation implicated in the report of a deficiency of salivary $\mathrm{CA}$ VI in CA II-deficient humans ${ }^{41}$ whose CA II and CA VI genes are known to be on chromosomes 8 and 1 , respectively. ${ }^{10,11}$

\section{Acknowledgements}

For kindly providing me with their unpublished results, I am indebted to Mounira Amor, Nils Bergenhem, Yvonne Edwards, Ross Fernley, Tommaso Meo and William Sly. I am particularly grateful to David HewettEmmett, as well as John Czelusniak and Morris Goodman, for preparing the 'tree' in Fig. 2, and also their welcome comments on other evolutionary aspects. I thank my colleagues, Richard 


\section{REVIEW ARTICLES}

Chegwidden, David Hewett-Emmett and Patrick Venta, for the many helpful discussions I had with them during the course of writing this review. Finally, I thank Jayne Long for her patient and excellent help during the preparation of the manuscript. Supported by NIH grant GM-24681.

\section{Note added in proof}

Results of recent ${ }^{18} \mathrm{O}$-exchange, activity measurements on human CA II in which Ala and Lys have been substituted for His at position 64 by sitedirected mutagenesis now indicate that His 64 , as predicted, does contribute to the catalytic mechanism through its role in the proton transfer pathway (D. N. Silverman and S. Lindskog, personal communication; Tu, C. K. et al., 1989, Biochemistry, in the press).

\section{REFERENCES}

1 Tashian, R. E. \& Hewett-Emmett, D. (ed.) (1984). Biology and chemistry of the carbonic anhydrases. Ann. N.Y. Acad. Sci. 429, 1-840.

2 Forster, R. E. (ed.) (1988). Velocity of $\mathrm{CO}_{2}$ exchange. Annu. Rev. Physiol. 50, 623-717.

3 Tashian, R. E. (1977). Evolution and regulation of the carbonic anhydrase isozymes. In Isozymes: Current Topics in Biological and Medical Research, vol. 2 (ed. M. C. Rattazzi, J. G. Scandalios and G. S. Whitt), pp. 21-62. Alan R. Liss, New York.

4 Venta, P. J., Montgomery, J. C., Hewett-Emmett, D., Wiebaler, K. \& TAShian, R. E. (1985). Structure and exon to protein domain relationships of the mouse carbonic anhydrase II gene. J. Biol. Chem. 260, 12130 12135 .

5 Yoshihara, C. M., Lee, J. D. \& Dodgson, J. B. (1987). The chicken carbonic anhydrase II gene: evidence for a recent shift in intron position. Nucl. Acids Res. 15, $753-770$.

6 Lloyd, J., Brownson, C., Tweedie, S., Charlton, J. \& EDwards, Y. H. (1987). Human muscle carbonic anhydrase: gene structure and DNA methylation patterns in fetal and adult tissues. Genes Dev. 1, 594-602. 7 Montgomery, J. C. (1988). Characterization of a human carbonic anhydrase-like gene with novel chromosomal location. Ph.D. thesis, University of Michigan.

8 Brady, H. J. M., Lowe, N., Sowden, J. C., Barlow, J. H. \& Butterwor TH, P. H. W. An unusual $5^{\prime}$-leader in the human erythroid-specific carbonic anhydrase I gene. Biochem. Soc. Trans. 17, 184-185.

9 Davis, M. B., West, L. F., Barlow, J. H., ButterWORTH, P. H. W., LloYd, J. C. \& EDWards, Y. H. (1987). Regional localization of carbonic anhydrase genes $C A I$ and $C A 3$ on human chromosome 8. Somat. Cell. Mol. Genet. 13, 173-178.

10 Nakai, H., Byers, M. G., Venta, P. J., Tashian, R. E. \& Shows, T. B. (1987). The gene for human carbonic anhydrase II (CA2) is located at chromosome $8 \mathrm{q} 22$. Cytogenet. Cell Genet. 44, 234-235.

11 Sutherland, G. R., Baker, E., Fernandez, K. E.
W., Callen, D. F., Aldred, P., Coghlan, J. P., Wright, R. D. \& FERnLEY, R. T. The gene for human carbonic anhydrase VI (CA VI) is on the tip of the short arm of chromosome 1. Cytogenet. Cell Genet. (In the press.) 12 Hewett-Emmett, D., Hopkins, P. J. \& Tashian, R. E. \& Czelusniak, J. (1984). Origins and molecular evolution of the carbonic anhydrase isozymes. Ann. N.Y. Acad. Sci. 429, 338-358.

13 Venta, P. J., Montgomery, J. C. \& Tashian, R. E. (1987). Molecular genetics of carbonic anhydrase isozymes. In Isozymes: Current Topics in Biological and Medical Research, vol. 14 (ed. M. C. Rattazzi, J. G. Scandalios \& G. S. Whitt), pp. 58-72. Alan R. Liss, New York.

14 Niles, E. G, Condit, R. C., Card, P., Davidson, K., Matusick, L. \& Sero, J. (1986). Nucleotide sequence and genetic map of the $16-\mathrm{kb}$ vaccinia virus HindIII D fragment. Virology 153, 96-112.

15 Niles, E. G. \& Seto, J. (1988). Vaccinia virus gene D8 encodes a virion transmembrane protein. J. Virol. $\mathbf{6 2}$, 3772-3778.

16 Debuire, B., Henry, C., Benaissa, C., Biserte, M., Claverie, G., Saule, J. M., Martin, P. \& Stehelin, D. (1984). Sequencing the erbA gene of avian erythroblastosis virus reveals a new type of oncogene. Science 224, 1456-1459.

17 Weinherger, C., Thompson, C. C., Ong, E. S., Leho, R., Gruol, D. J. \& Evans, R. S. (1986). The c-erb- $A$ gene encodes a thyroid hormone receptor. Nature 324, $641-646$.

18 Notstrand, B., VaAra, I. \& Kannan, K. K. (1974). Structural relationship of human erythrocyte carbonic anhydrase isozymes B and C. In Isozymes: Molecular Structure, vol. I (ed. C. L. Market), pp. 575-599. Academic Press, New York

19 Eriksson, A. E. (1988). Structural differences between high and low activity forms of carbonic anhydrases. Ph.D. thesis, University of Uppsala, Sweden. 20 Gros, G. \& Dodgson, S. J. (1988). Velocity of $\mathrm{CO}_{2}$ exchange in muscle and liver. Annu. Rev. Physiol. 50 , 669-694.

21 Forsman, C., Behravan, G., Jonsson, B. H., Liang, Z. W., Lindskog, S., Ren, X., SANDSTrom, J. \& WALLGREN, K. (1988). Histidine 64 is not required for high $\mathrm{CO}_{3}$ hydration activity of human carbonic anhydrase II. FEBS Lett. 228, 360-362.

22 LindskoG, S. (1983). Carbonic anhydrase. In Zinc Enzymes (ed. T. G. Spiro), pp. 79-121. John Wiley, New York.

23 Jeffery, S., Wilson, C., Mode, A., Gustafsson, J. A. \& CARTER, N. (1986). Effects of hypophysectomy and growth hormone infusion on rat hepatic carbonic anhydrase. J. Endocrin. 110, 123-126.

24 Carter, N., Jeffifry, S., Legg, R., Wistrand, P. \& LONNERHOLM, G. (1987). Expression of hepatocyte carbonic anhydrase isoenzymes in vitro and in vivo. Biochem. Soc. Trans. 15, 667-668.

25 Jefrery, S., Carter, N. D. \& SMith, A. (1987) Thyroidectomy significantly alters carbonic anhydrase II concentration and fiber distribution in rat muscle. $J$ Histochem. Cytochem 36, 663-668.

26 Frémont, P., Lazure, C., Tremblay, R. R., CrétIEN, M. \& Rogers, P. A. (1987). Regulation of carbonic anhydrase III by thyroid hormone: opposite modulation in slow- and fast-twitch skeletal muscle. Biochem. Cell Biol. 65, 790-797.

27 Carter, N., Wistrand, P., Isenberg, H., Askmark, H., JeFFery, S., Hopkinson, D. \& EDWARDS, Y. (1988) Induction of carbonic anhydrase III $m R N A$ and protein by denervation of rat muscle. Biochem. J. 256, 147-152 28 HARKoneN, P. L. \& VÄÄNÄNEN, H. K. (1988). Androgen regulation of carbonic anhydrase II, a major soluble protein in rat lateral prostate tissue. Biology Repro. 38, 377.-384.

29 arlot-Bonnemains, Y Fouchereau-Peron, B., Moukhtar, M. S., Benson, A. A. \& Milhaud, G. (1985). Calcium-regulating hormones modulate carbonic anhydrase II in the human erythrocyte. Proc. Natl. Acad. Sci. USA 82, 8832-8834.

30 Frémont, P., Charest, P. M., Côté, C. \& Rogers P. A. (1988). Carbonic anhydrase III in skeletal muscle fibers: an immunocytochemical and biochemical study. J. Histochem. Cytochem. 36, 776-782.

31 Dodgson, S. J. \& Contino, L. C. (1987). Rat kidney mitochondrial carbonic anhydrase. Arch. Biochem. Biophys. 260, 334-341.

32 Hewett-Emmett, D., CoOK. R. G. \& Dodgson, S. J. (1988). Novel gene encodes mitochondrial carbonic anhydrase $(\mathrm{CA} \mathrm{V})$ that lacks the active-site tyrosine of the amino-terminal region of CA I, CA II and CA III. Fed. Proc. 45, 1661.

33 Coulson, R. A. \& Herbert, J. D. (1984). A role for carbonic anhydrase in intermediary metabolism. Ann. N.Y. Acad. Sci. 429, 506-515.

34 Sly, W. S., White, M. P., Sundaram, V., Tashian R. E., Hewett-Emmett, D., Guibaud, P. Vainsel., M. Baluarte, H. J., Grushin, A., Al-Mosawi, A. Sakati, N. \& Ohlsson, A. (1985). Carbonic anhydrase II deficiency in 12 families with the autosomal recessive syndrome of osteopetrosis with renal tubual acidosis and cerebral calcification. N. Eng. J. Med. 313, 139-145. 35 Dodgson, S. J., Forster, R. E., Sly, W. S. \& TASHIAN, R. E. (1988). Carbonic anhydrase activity of intact CA II-deficient human erythrocytes. J. Applied Physiol. 65, 1472-1480.

36 Lewis, S. E., Erickson, R. P., Barnett, L. B Venta, P. J. \& Tashian, R. E. (1988), $N$-ethyl- $N$ nitrosourea-induced null mutation at the mouse $\mathrm{Car}^{-2}$ locus : an animal model for human carbonic anhydrase II deficiency syndrome. Proc. Natl. Acad. Sci. USA 85, 1962-1966.

37 Fernley, R. T., Wright, R. D. \& Coghlan, J. P. (1988). Complete amino acid sequence of ovine salivary carbonic anhydrase. Biochemistry 27, 2815-2820

38 Fraser, P. J. \& Curtis, P. J. (1986). Molecular evolution of the carbonic anhydrase genes: calculations of divergence time for mouse carbonic anhydrase I and II. J. Mol. Evol. 23, 294-299.

39 WendorfF, K. M., Nishita, T., Jabusch, J. R. \& Deutsch, H. F. (1985). The sequence of equine muscle carbonic anhydrase. J. Biol. Chem. 260, 6129-6132.

40 Spicer, S. S., Lewis, S. E., Tashian, R. E. \& Schul TE, B. A. (1989). Mice carrying a Car-2 null allele lack carbonic anhydrase II immunochemically and show vascular calcification. Am. J. Pathol. (In the Press.)

41 Murakami, H. \& Sly, W. S. (1987). Purification and characterization of human salivary carbonic anhydrase. J. Biol. Chem. 262, 1382-1388.

42 Spicer, S. S., Ge, Z.-H., Tashian, R. E., HazenMartin, D. J. \& Schulte, B. A. (1989). Comparative distribution of carbonic anhydrase isozyme III and II in rodent and human tissues. Am. J. Anat. (In the Press.)

RICHARD E. TASHIAN is at the Department of Human Genetics, University of Michigan Medical School, Ann Arbor, MI 48109, USA

\section{REVIEWS FOR BIOESSAYS}
Although review articles for BioEssays are normally solicited by members of the Editorial Board, unsolicited reviews will be considered. If you are interested in writing a review article, please send a short résumé outlining the subject and scope of the proposed piece, with a brief description of your scientific background, to the Staff Editor, BioEssays, Cambridge University Press, The Edinburgh Bldg., Shaftesbury Rd., Cambridge CB2 2RU, United Kingdom. 